\title{
MEMBANGUN APLIKASI PENJUALAN DAN DATA BARANG PADA TOKO SEPEDA FORMULA BIKE
}

\author{
Didik Supriyadi \\ Teknik Informatika, Fakultas Teknik dan Ilmu Komputer, Universitas Indraprasta PGRI Jakarta \\ Jalan Raya Tengah No 80, Kelurahan Gedong, Pasar Rebo, Jakarta Timur \\ didiksupriyadi643@gmail.com
}

\begin{abstract}
ABSTRAK
Permasalahan yang terdapat pada Toko Sepeda Formula Bike adalah proses pembelian dan transaksi penjualan masih manual dengan menggunakan buku besar dalam setiap pencatatan nya, sehingga sering terjadi kesalahankesalahan yang akan menyebabkan kerugian bagi Toko Sepeda Formula Bike dan pembuatan laporan kepada pemilik toko masih membutuhkan banyak waktu sehingga tidak efisien. Tujuan merancang suatu sistem informasi pembelian dan penjualan ini dengan tujuan untuk mempercepat proses pengolahan data-data yang ada di Toko, kemudian mempermudah dalam pencarian data serta pembuatan laporan yang dibutuhkan oleh pemilik Toko. Perangkat aplikasi yang telah dibuat dengan bahasa pemrograman Java NetBeans 8.0.2 dan penyimpanan data pada database MySQL dapat memberikan kelancaran dalam proses menginput dan penyimpanan data-data serta laporan-laporan yang diberikan kepada pemilik toko. Dengan menggunakan metode penelitian Research and Development dapat menyelesaikan permasalahan yang ada di Toko Sepeda Formula Bike. Hasil dari penelitian ini menciptakan suatu sistem informasi pembelian dan penjualan dapat memudahkan pihak toko dalam proses pendataan data barang, data pembelian barang, data penjualan serta data return pembelian yang lebih baik dan akurat.
\end{abstract}

Kata Kunci: Aplikasi, Penjualan, Desktop

\section{ABSTRACT}

The problem with the Formula Bike Bike Shop is that the buying process and sales transactions are still manual by using a ledger in every record, so mistakes often occur that will cause losses for the Formula Bike Bike Shop and making reports to shop owners still takes a lot of time. so inefficient. The purpose of designing a buying and selling information system is to speed up the processing of data in the store, then make it easier to search for data and make reports needed by store owners. Applications that have been made with the Java NetBeans 8.0.2 programming language and data storage in the MySQL database can provide smooth processing of input and storage of data and reports provided to shop owners. By using Research and Development research methods can solve the problems that exist in the Formula Bike Bike Shop. The results of this study create a purchasing and sales information system that can facilitate the store in the process of collecting data on goods, purchase data, sales data and purchase return data that is better and more accurate.

Key Word: Application, Selling, Desktop

\section{PENDAHULUAN}

Perkembangan arus globalisasi yang diiringi dengan perkembangan teknologi informasi menyebabkan arus informasi yang dulunya sulit didapat kini dapat dengan mudah diperoleh sesuai dengan kebutuhan (Ali, 2019). Perkembangan teknologi yang semakin maju menuntut suatu kinerja dalam sebuah instansi atau perusahaan yang relatif cepat dan tepat untuk menghasilkan informasi yang dibutuhkan (Nurhayati, Josi, \& Hutagalung, 2018). Salah satunya penerapan teknologi komputer sebagai alat bantu yang mutlak dipergunakan sebagai pendukung utama dalam persaingan bisnis dan dukungan sumber daya manusia yang baik. Untuk dapat menciptakan dan menghadapi kondisi yang demikian, perlu adanya sistem informasi yang dapat melayani segala macam aspek informasi yang menyangkut kemampuan, kecakapan, keahlian, pengalaman dan potensi karyawan secara cepat, tepat, dan akurat yang selanjutnya dapat digunakan dalam penetapan kebijaksanaan atau keputusan serta pelaksanaan dalam pengolahan data serta sistem informasi penjualan dan data barang di Toko Sepeda Formula Bike Ciputat agar bisa berkembang (Hariyanto, 2016). 
Toko Sepeda Formula Bike Ciputat merupakan toko sepeda yang profesional yang bergerak dibidang jual beli sepeda dengan didukung oleh tenaga ahli berpendidikan yang kredibel. Tetapi ada permasalahan didalam pendataan proses penjualan dan proses pendataan karena semuanya dikerjakan secara manual tidak adanya suatu sistem informasi sebagai penunjang proses tersebut (Mauluddin \& Santini, 2017).

Permasalahan yang paling signifikan adalah pada proses penginputan data, proses pembelian barang ke supplier dan transaksi penjualan serta laporan ini masih dilakukan secara manual, sehingga data yang didapat seringkali bermasalah karena kesalahan dari manusia, misalnya ketika bagian administrasi membutuhkan informasi mengenai stok barang masuk dan barang keluar maka harus dilakukan pengecekan ke gudang dan melakukan pengontrolan barang. Pelaporan data penjualan sering sekali terlambat pada saat penyerahan laporan bulanan kepada pemilik toko (Ananda \& Zuraidah, 2019).

Perancangan sistem informasi yang akan diterapkan dapat memudahkan dalam pengolahan data sehingga mendapatkan manfaat yaitu membantu pengolahan data secara terkomputerisasi untuk memudahkan dan mempercepat proses transaksi, memudahkan pencarian data, memudahkan pembuatan laporan dan meminimalisir kesalahan proses jual beli (Hariyanto, 2014).

Dengan permasalahan tersebut, perlu ada nya suatu sistem yang terkomputerisasi dalam penyelesaiannya. Sistem informasi yang dirancang merupakan sekelompok unsur yang erat hubungannya satu dengan yang lain, yang berfungsi bersama-sama untuk mencapai tujuan (Sutabri, 2012). Pembangunan sistem merupakan sekumpulan aktivitas yang menggambarkan secara rinci bagaimana sistem akan berjalan. Hal itu bertujuan untuk menghasilkan produk perangkat lunak yang sesuai dengan kebutuhan user (Satzinger, J. W., Jackson, R. B., Burd, n.d.).

Diharapkan dengan adanya suatu sistem informasi dapat menangani permasalahan yang ada di perusahaan tersebut. Sistem adalah setiap sesuatu terdiri dari obyek-obyek, atau unsur-unsur, atau komponen-komponen yang bertata kaitan dan bertata hubungan satu sama lain, sedemikian rupa sehingga unsur-unsur tersebut merupakan satu kesatuan pemrosesan atau pengolahan yang tertentu. (Prasojo, 2011)

Aplikasi ini dapat memudahkan pekerjaan Admin dalam melaksanakan pembuatan laporan dan dapat memudahkan toko dalam memproses penginputan, pencarian data serta transaksi penjualan pada Toko Sepeda Formula Bike.

\section{METODE PENELITIAN}

Peneliti menggunakan metode Research and Development dalam penyelesaian penelitian ini. (Sugiyono, 2016). Dalam pelaksanaan R\&D, ada beberapa metode yang digunakan yaitu metode deskriptif, evaluatif dan eksperimental. Metode penelitian deskriptif digunakan dalam penelitian awal untuk menghimpun data tentang kondisi yang ada yaitu penulis membutuhkan data-data yang dapat menunjang tercipta nya suatu sistem informasi penjualan seperti data barang, data pelanggan, data pembelian data penjualan dan data return pembelian terdahulu yang masih tersimpan secara manual didalam buku besar. Metode evaluatif digunakan untuk mengevaluasi proses ujicoba pengembangan suatu produk, dalam proses ini penulis melakukan ujicoba terhadap suatu sistem yang telah dirancang agar tidak ada terjadi kesalahan dalam proses penginputan data serta pelaporan bulanan kepada pemilik toko. Dan metode eksperimen digunakan untuk menguji keampuhan dari produk yang dihasilkan, dalam proses yang terakhir ini perlu dilakukan pengujian akhir yang diharapkan bahwa sistem yang dirancang oleh penulis dapat berjalan dengan baik dan sesuai dengan kebutuhan dan terfokus pada proses penginputan data dan transaksi penjualan pada Toko Sepeda Formula Bike (Putra, 2011).

\section{HASIL DAN PEMBAHASAN Analisa Permasalahan}

Dari pembahasan diatas penulis mengambil simpulan atas permasalahan yang ada diantaranya:

1. Penulisan data masih dilakukan secara manual dalam pencatatan data pembelian dan penjualan maupun dalam pembuatan laporan.

2. Proses pencatatan secara manual memerlukan tempat penyimpanan yang sangat luas, akibat 
kertas yang bertumpuk serta memerlukan waktu yang lama dalam proses pencarian kembali data.

3. Pelayanan terhadap pelanggan menjadi tidak efisien dan mungkin akan terjadi kesalahan akibat waktu yang lama dalam pencarian data.

\section{Alternatif Penyelesaian Masalah}

Berdasarkan analisis sistem yang sedang berjalan saat ini penulis melihat kelemahan-kelemahan dan pokok permasalahan yang terdapat pada sistem pembelian dan penjualan pada Toko Sepeda Formula Bike, maka penulis dapat menyarankan beberapa alternatif permasalahan yang dapat dicoba, yaitu:

1. Agar tidak terjadi keterlambatan didalam proses pengerjaan informasi, sebaiknya dikoordinasi dengan baik dan terkomputerisasi dengan benar antara sub sistem yang satu dengan yang lainnya, dan sebaiknya Toko Sepeda Formula Bike membuat rancangan sistem yang dapat meringankan dalam bertransaksi, membuat laporan, mengecek data-data khususnya pada penjualan.

2. File atapun data yang sudah dikerjakan sebaiknya disimpan ke Harddisk ataupun alat penyimpanan data yang lain, dan jika perlu dibuat backupnya jika saat teradi kesalahan memiliki cadangan file ataupun data-data.

3. Alangkah baiknya bila komputer yang digunakan untuk memproses data di upgrade, sehingga pemrosesan data tersebut dapat dilakukan lebih baik, cepat dan tepat.

Dirancangnya suatu sistem informasi pembelian dan penjualan pada Toko Sepeda Formula Bike yang terkomputerisasi ini, diharapkan dapat mempermudahkan proses pengerjaan dan pengecekan data khususnya pada proses pembuatan laporan dan transaksi penjualan.

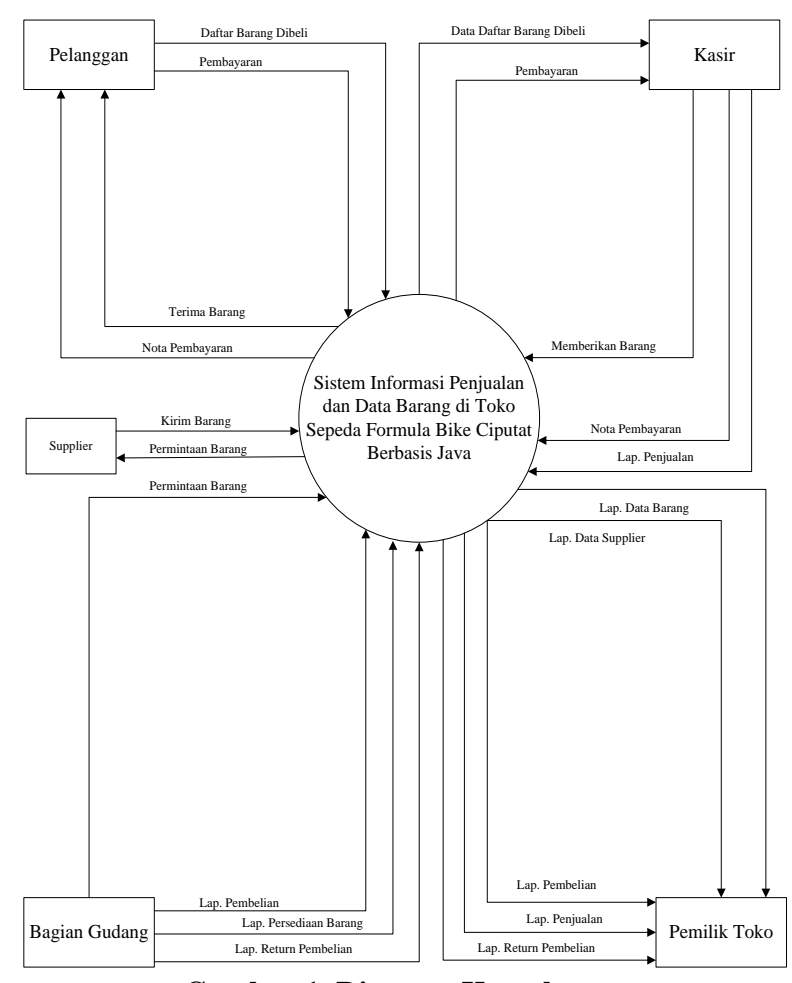

Gambar 1. Diagram Konteks

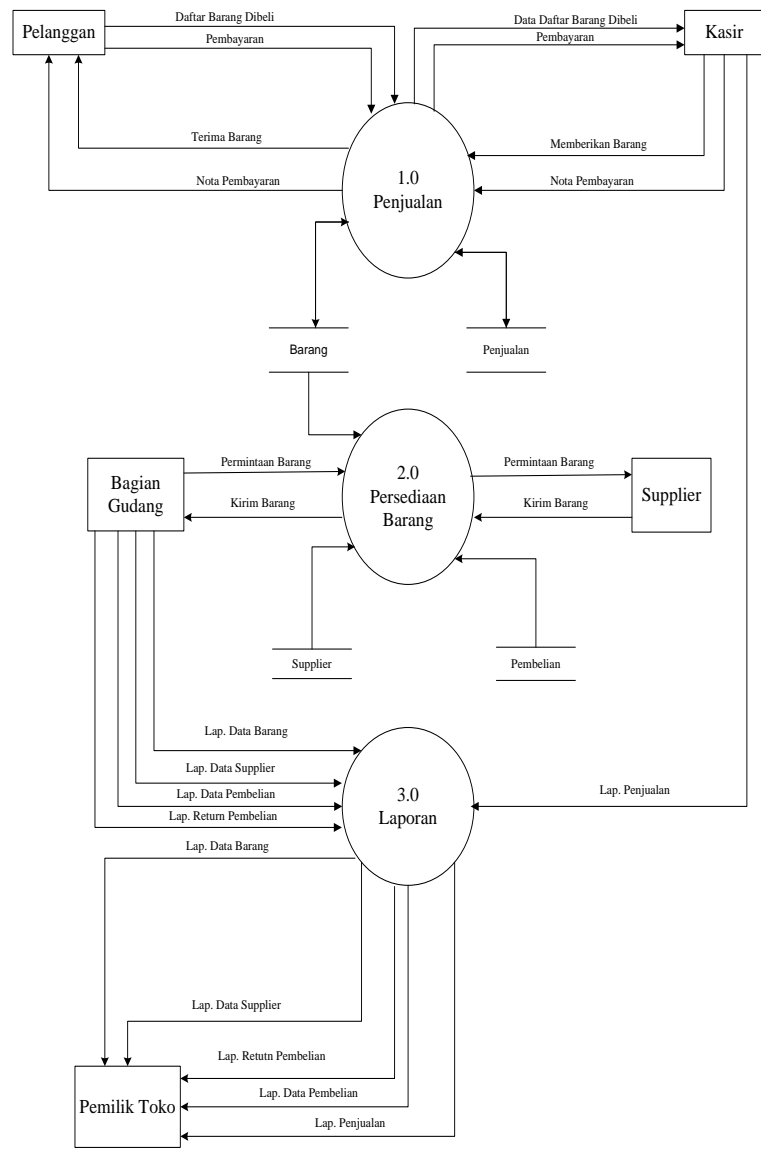

Gambar 2. Diagram Nol 


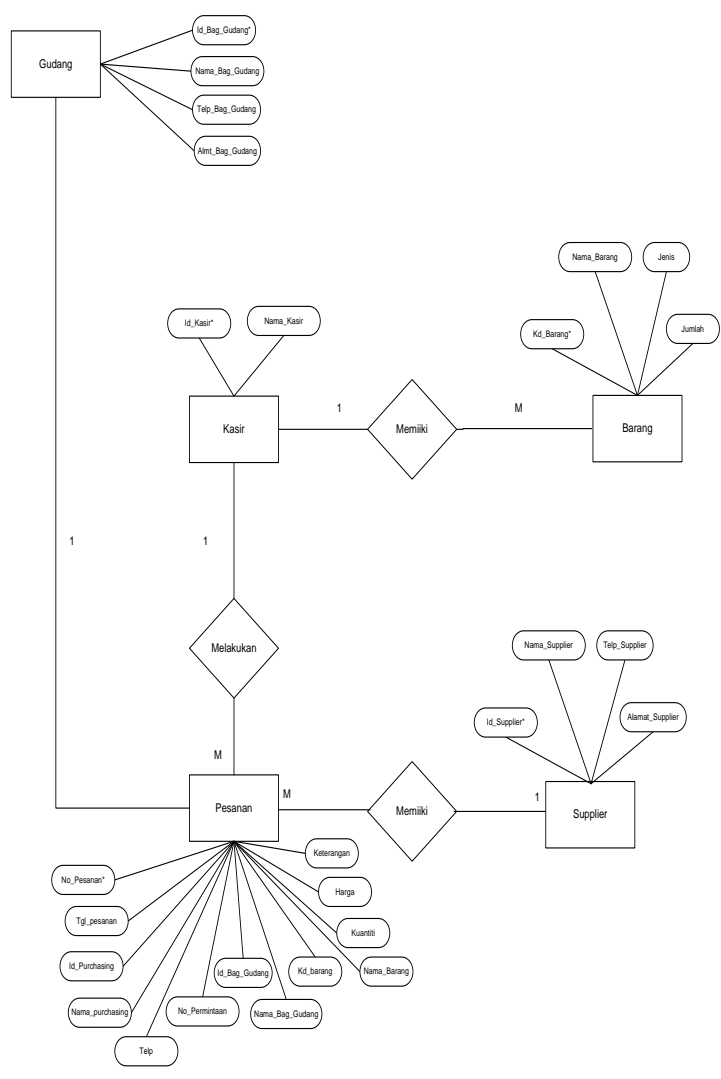

Gambar 3. Entity Relationship Diagram

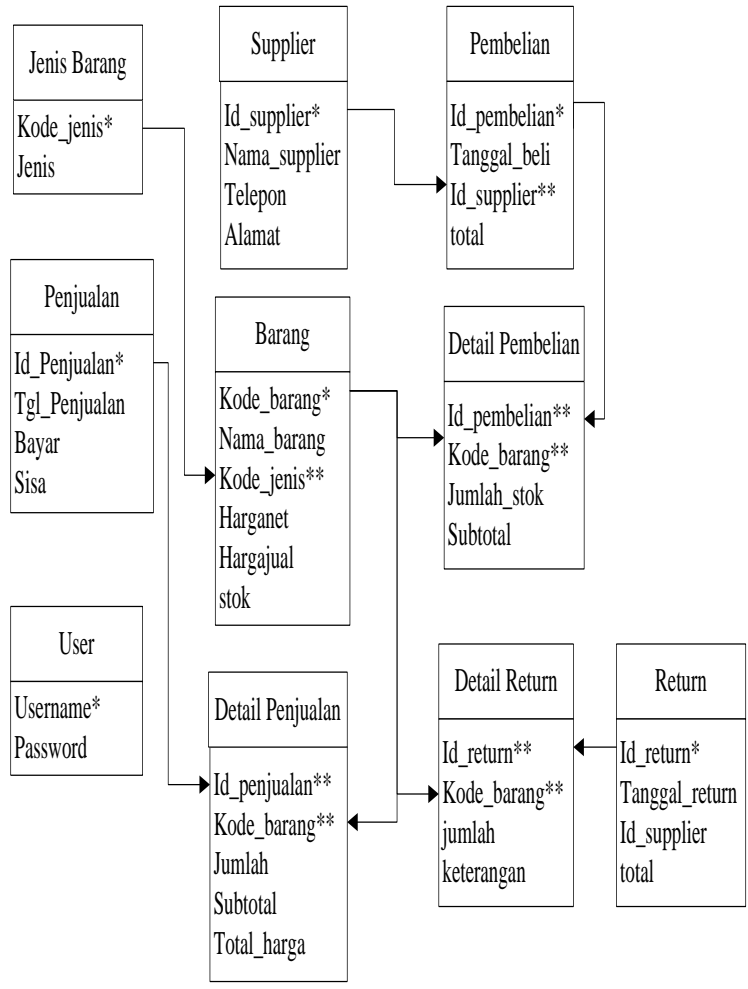

Gambar 4. Normalisasi
Berikut adalah tampilan layar dan hasil pengujian pada software program yang telah di buat dengan bahasa pemrograman Java.

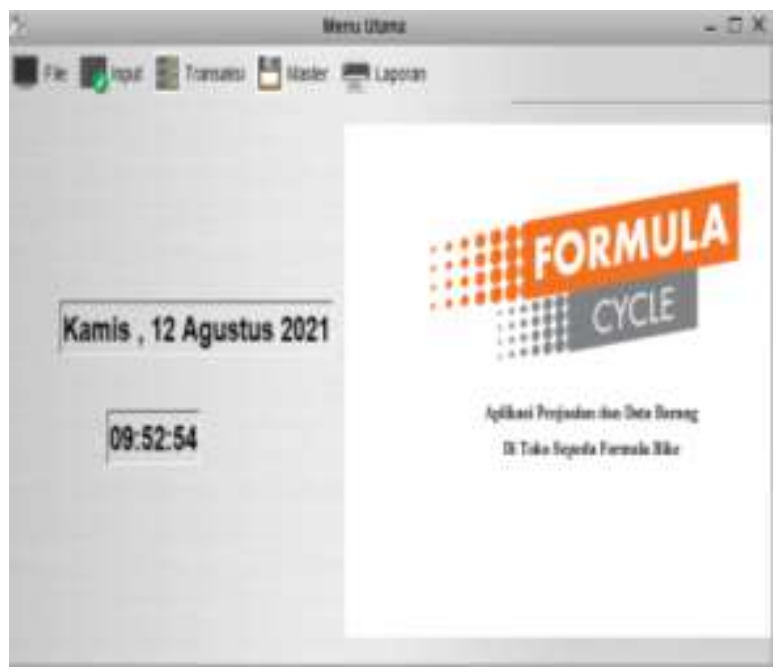

Gambar 5. Form Menu Utama

Layar di atas menampilkan tampilan Menu Utama pada Aplikasi Penjualan dan Data Barang Di Toko Sepeda Formula Bike. Pada layar utama tersedia menu bar yang terdiri dari master data yang digunakan untuk memasukkan data yang berkaitan dengan data jenis barang, data barang, data supplier, data pembelian, data penjualan, data return pembelian, dan laporan-laporan.

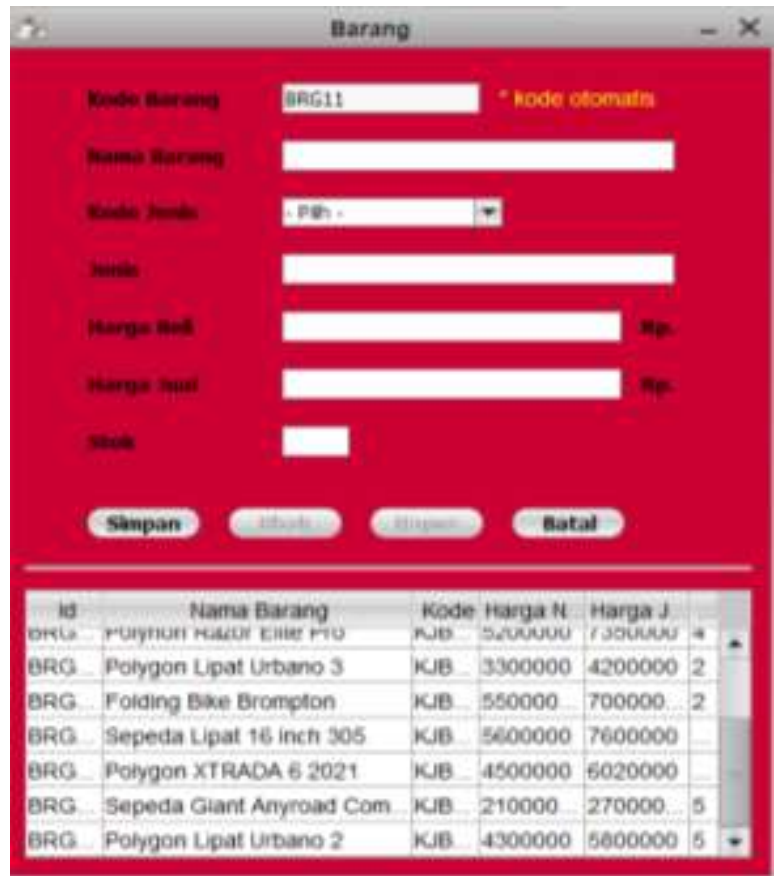

Gambar 6. Form Data Barang

705 | Membangun Aplikasi Penjualan dan Data Barang pada Toko Sepeda Formula Bike 
Layar di atas menampilkan tampilan form data barang. Pada layar form data barang untuk menginput data barang yang terdiri dari Kode Barang, Nama Barang, Kode Jenis, Jenis Barang, Harga Beli, Harga Jual dan Stok.

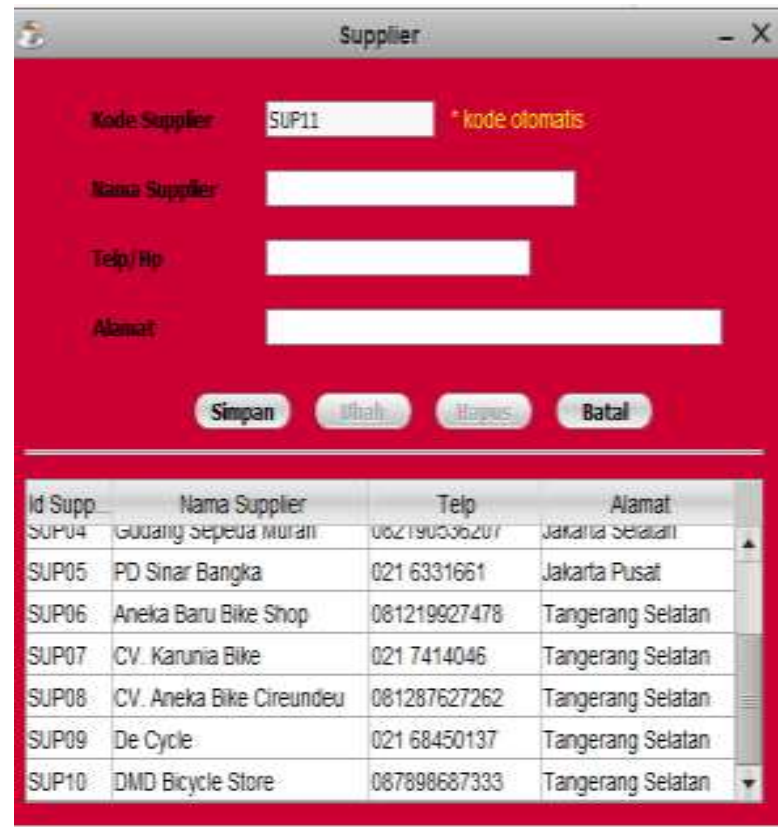

Gambar 7. Form Data Supplier

Layar di atas menampilkan tampilan form data supplier. Pada layar form data supplier untuk meng-input data supplier yang terdiri dari Kode Supplier, Nama Supplier, No Telp dan Alamat.

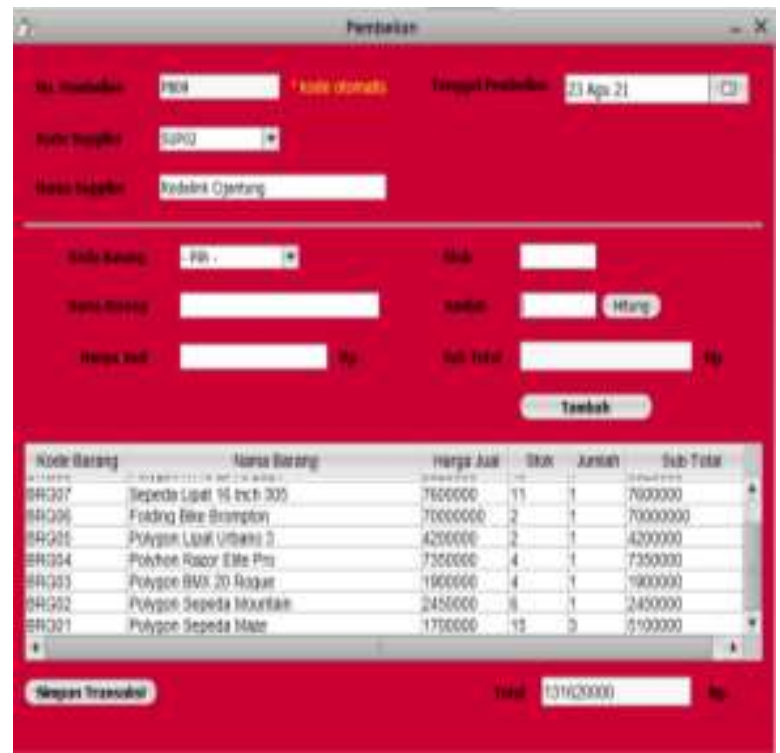

Gambar 8. Data Form Data Transaksi Pembelian
Layar di atas menampilkan tampilan form data transaksi pembelian. Pada layar form data transaksi pembelian untuk meng-input data transaksi pembelian yang terdiri dari No Pembelian, Tgl Pembelian, Kode Supplier, Nama Supplier, Kode Barang, Nama Barang, Harga Jual, Stok, Jumlah dan Sub Total.

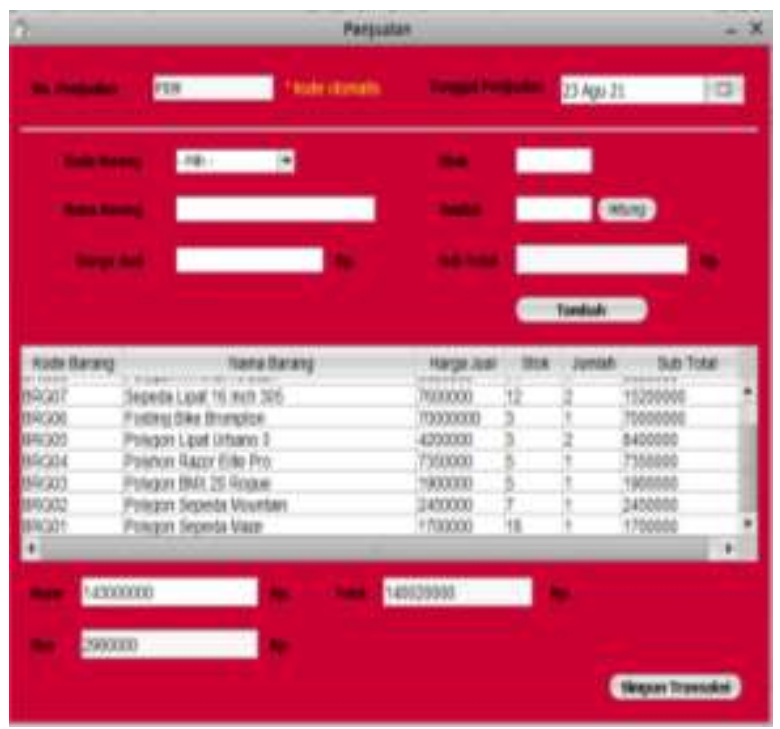

Gambar 9. Form Data Transaksi Penjualan

Layar di atas menampilkan tampilan form data transaksi penjualan. Pada layar form data transaksi penjualan untuk meng-input data transaksi penjualan yang terdiri dari No Penjualan, Tgl Penjualan, Kode Barang, Nama Barang, Harga Jual, Stok, Jumlah dan Sub Total.

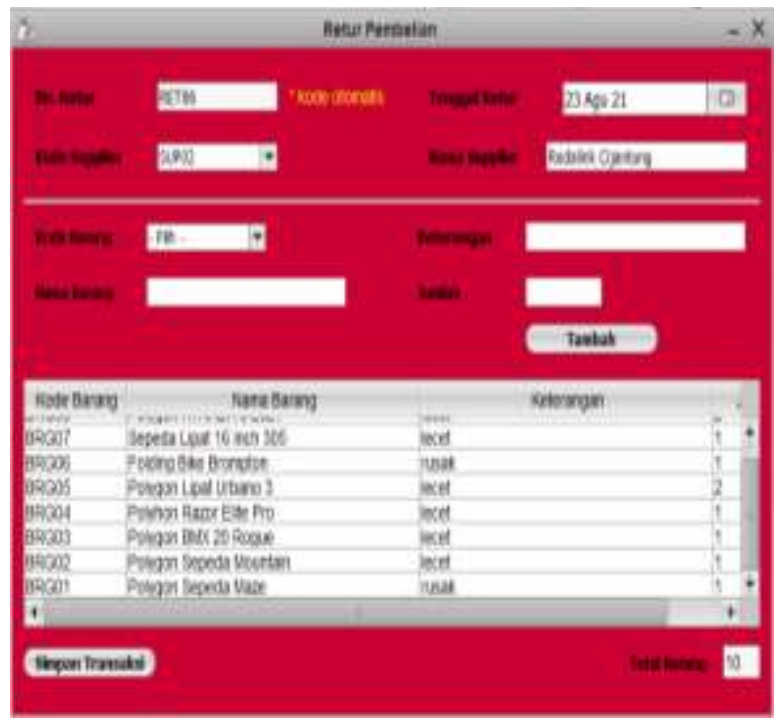

Gambar 10. Form Data Return Pembelian

706 | Membangun Aplikasi Penjualan dan Data Barang pada Toko Sepeda Formula Bike 
Layar di atas menampilkan tampilan form data return pembelian. Pada layar form data return pembelian untuk meng-input data return pembelian yang terdiri dari No Retur, Kode Supplier, Nama Supplier, Tanggal Retur, Kode Barang, Nama Barang, Keterangan dan Jumlah.

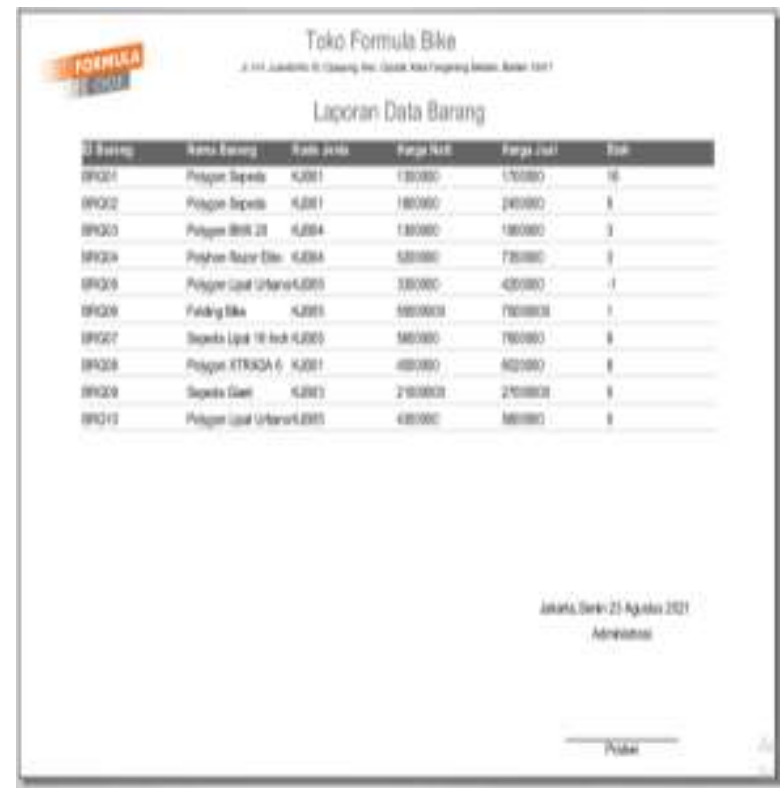

Gambar 11. Laporan Data Barang

Layar di atas menampilkan tampilan form laporan data barang. Pada layar form data barang digunakan untuk mengecek laporan data barang terdiri Kode Barang, Nama Barang, Kode Jenis, Jenis Barang, Harga Beli, Harga Jual dan Stok.

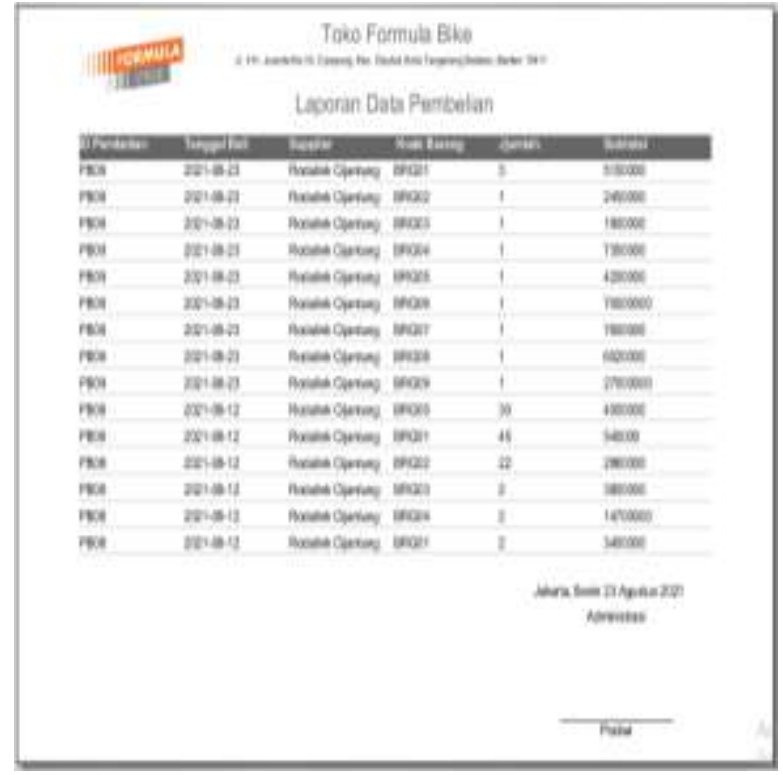

Gambar 12. Laporan Data Pembelian
Layar di atas menampilkan tampilan bukti pengembalian mobil. Pada layar bukti pengembalian mobil terdiri dari Kode Pengembalian, Tgl Kembali, ID Petugas, Nama Petugas, ID Booking, NIK, Nama Karyawan, Model dan Keterangan.

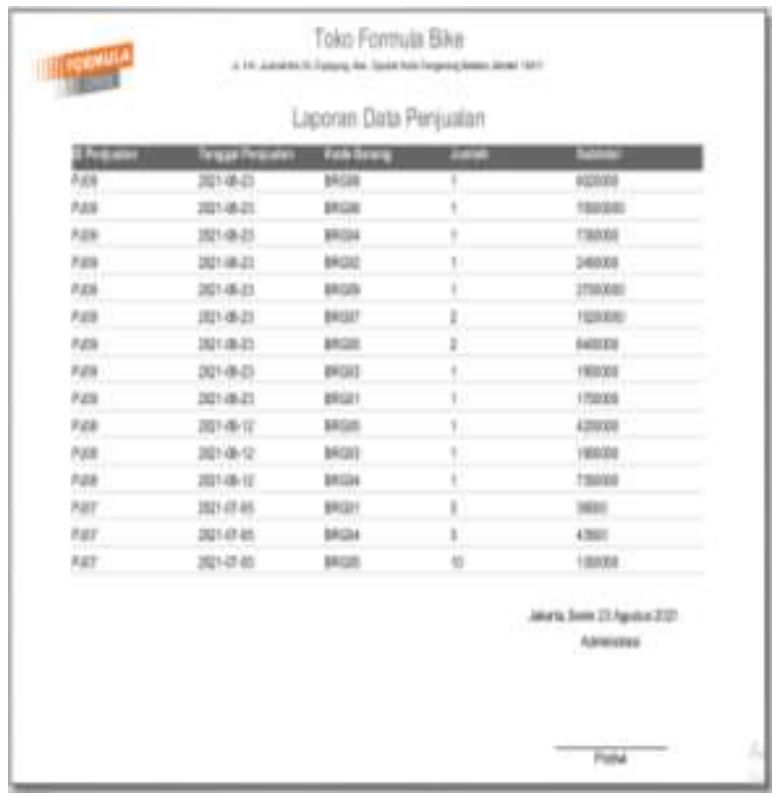

Gambar 13. Laporan Data Penjualan

Layar di atas menampilkan tampilan form laporan data penjualan. Pada layar form data penjualan digunakan untuk mengecek laporan data penjualan terdiri No Penjualan, Tgl Penjualan, Kode Barang, Jumlah dan Sub Total.

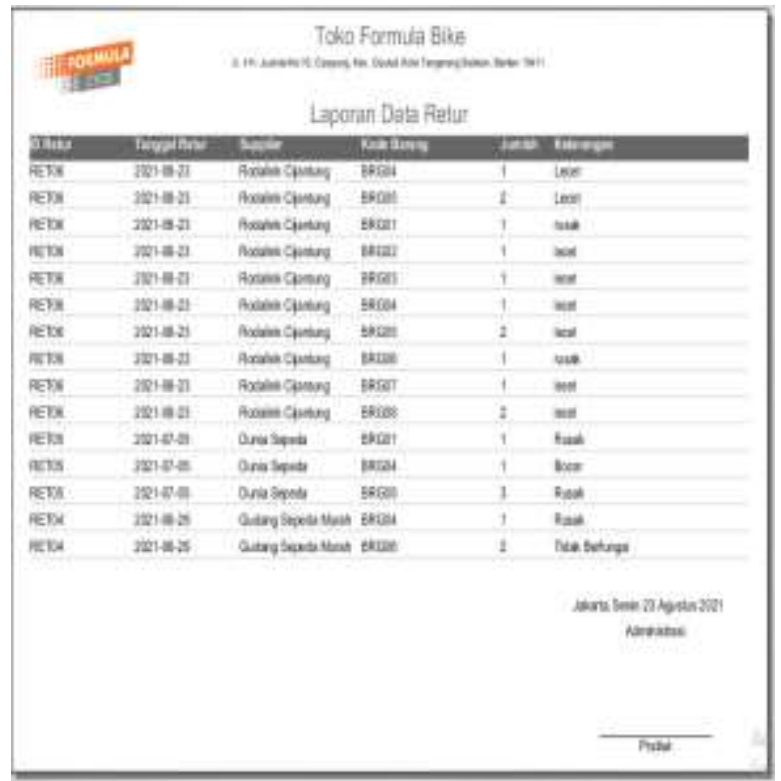

Gambar 14. Laporan Data Return Pembelian 
Layar di atas menampilkan tampilan form laporan data retur pembelian. Pada layar form data retur pembelian digunakan untuk mengecek laporan data retur pembelian terdiri No Retur, Tanggal Retur, Nama Supplier, Kode Barang, Jumlah, Keterangan.

\section{SIMPULAN DAN SARAN}

Aplikasi penjualan yang dirancang dengan menggunakan bahasa pemrograman Java dan MySQL berbasis desktop ini dapat meningkatkan kinerja admin dalam proses pendataan sehingga menjadi lebih baik dan akurat. Sistem aplikasi yang dirancang sudah layak digunakan untuk proses penjualan pada Toko Sepeda Formula Bike karena sudah sesuai dengan kebutuhan.

Sarannya adalah dengan penggunaan aplikasi penjualan ini bagi admin pada Toko Formula Bike ada beberapa hal yang harus diperhatikan yaitu ketelitian dan kecermatan dibidang komputer harus diperhatikan dengan sungguh-sungguh dan diperlukan adanya tenaga ahli yang terampil, baik dalam mengoperasikan maupun pengontrolan software.

\section{DAFTAR PUSTAKA}

Ali, A. F. (2019). Rancang Bangun Aplikasi Penjualan Barang Berbasis Java Programming. Simtika.

Ananda, I., \& Zuraidah, E. (2019). Perancangan Sistem Informasi Penjualan Barang Pada PT Asia Truk Pratama Jakarta. Jurnal Informatika. https://doi.org/10.31311/ji.v6i2.6248

Hariyanto. (2014). Permasalahan Bahasa Pemograman Java. Bandung: Informatika Bandung.

Hariyanto, D. (2016). Rancang Bangun Sistem Informasi Pembelian dan Penjualan Barang Berbasis Website ( Studi Kasus: CV . Samdhika Elektronik Depok ). Swabumi, IV(2), 152-166.

Mauluddin, S., \& Santini, N. (2017). Sistem Informasi Persediaan Dan Penjualan Barang Berbasis Desktop. Prosiding Saintiks FTIK UNIKOM.

Nurhayati, A. N., Josi, A., \& Hutagalung, N. A. (2018). Rancang Bangun Aplikasi Penjualan dan Pembelian Barang Pada Koperasi Kartika Samara Grawira Prabumulih. Jurnal
Teknologi

Dan

Informasi. https://doi.org/10.34010/jati.v7i2.490

Prasojo, M. (2011). Pengantar Sistem Informasi Manajemen . bandung: CV. Remadja Karya.

Putra, N. (2011). Research and Development, Penelitian dan Pengembangan: Suatu Pengantar. Jakarta: PT Raja Grafindo Persada.

Satzinger, J. W., Jackson, R. B., Burd, S. D. (n.d.). System Analysis and Design in A Changing World. USA: Cengage Learning.

Sugiyono. (2016). Metode Penelitian Kuantitatif, Kualitatif dan $R \& D$. Bandung: PT Alfabet.

Sutabri, T. (2012). Analisis Sistem Informasi. Yogyakarta: Andi.

Tyoso, J. S. P. (2016). Sistem Informasi Manajemen. Yogyakarta: DeePublish. 